\section{HOW COULD WE OBSERVE CHANGE OF THE EXCHANGE RATE? REVIEW OF SELECTED FACTORS OF INFLUENCE ON FOREIGN EXCHANGE MARKET}

\section{GENESIS AND BASIC PRINCIPLES OF THE FOREIGN EXCHANGE MARKET}

By the broadest definition, the exchange rate represents the meeting of supply and demand for foreign exchange $(1,97)$. Foreign exchange markets have developed throughout history, and their development has been largely influenced by the Smithsonian and Bretton Woods agreements. Later, in the 1970s, Nobel laureate Milton Friedman actively advocated the introduction of a floating exchange rate and the introduction of a monetarist approach for the sake of market efficiency and the benefits created by economic policy. In particular, two of Milton Friedman's works have raised awareness of the need for change, namely: Theoretical Frameworks of Monetary Analysis (1970) and Monetary Theory of Nominal Income (1971) $(2,160)$ When forming the monetarist approach and abandoning Keynesianism as a theory, the main trump cards of the new approach were related to market liberalization and quantitative monetary theory (3). From 1972 to 1973, after the acceptance and implementation of a floating exchange rate by world leaders, the Foreign Exchange Market (FOREX) was created (4). The existence of the Forex market further enabled the development of currency trading. The currency market allows many users for various purposes when conducting transactions, which is why there has been rapid progress in the flow of money in that market from its inception until today. As early as 1977, the daily capital flow in the foreign exchange market was about five billion dollars (5). The development of the inter-

\section{SUMMARY}

Key words: international foreign exchange market, exchange rate, factors influencing the currency market

This paper defines the participants in the international foreign exchange market and the influence of natural, political, and economic factors on the movement of the exchange rate, and analysis of circumstances that may contribute to the change of the exchange rate. The paper aims to present the analysis of the exchange rate through macroeconomic phenomena and define the factors influencing the change in the exchange rate and the impact on the work of participants in that process. As risk management measures can prevent the influence of significant factors defined in the paper, measures, and types of risk exposure are determined.

Milorad Stamenović, PhD, Université Côte D’Azur, Nice, France, e-mail: milorad.stamenovic@skema.edu

Sanja Jelisavac Trošić, Ph.D, Senior Research Fellow, Institute of International Politics and Economics, Serbia, e-mail: sanja@ diplomacy.bg.ac.rs 
national foreign exchange market (in the context of the amount of money daily) was made possible by the idea that arose in 1986 and advocated that people who want to trade the Forex market and have less than $\$ 100,000$ in deposits be allowed to trade with fewer sums of money. In this way, leverage was introduced to private investors. Commercial banks are an important participant in the Foreign Exchange Market because they have a large capital on a global level, as well as the appropriate logistics to include that capital in world money flows through the international currency market. Banks are the largest participants in the forex market. They are in charge of issuing quotations - buying and selling rates, which obliges them to buy and sell currency at these rates (of course, with certain fees) when conducting transactions. In current conditions, banks perform transactions quickly and efficiently through the computer network SWIFT (Society of Worldwide Interbank Financial Telecommunication) (7). After banks, portfolio managers, hedge funds, and mutual funds represent the largest group of participants in the Forex market (8). Investment managers trade currencies with large pension fund accounts or other mutual funds. Investment managers with an international trading portfolio buy and sell currency to trade in the international foreign exchange market. Individuals participate in trading on the international foreign exchange market with a percentage of about $5 \%$ and appear as speculators on the international foreign exchange market, so their role is to make a profit based on differences in buying or selling currencies. It is very important for individual participants in the international foreign exchange market to be thoroughly acquainted with the risks that trading on the international foreign exchange Forex market brings. Multinational corporations (hereinafter MNC), which are economically stronger than many countries in the world, in their business on a daily basis, face the issue of the risk related to their business (6). Because MNCs participate in different markets and on an international basis, the risks that occur are higher and more extensive than in domestic corporations (3). The Central bank behaves in such a way as to monitor the effects of inflation on its economy. The impact of inflation is reflected in the growth or decline in the purchasing power of the population. By monitoring the consumer basket, an index can be determined on the basis of which inflationary trends can be monitored (9). Inflation is a market effect that will be felt by all market participants regardless of whether they are involved in trading or not. In times of high inflation, employees will ask for more money for their work because the previous per diem that was calculated no longer has the same real value. To meet employees in connection with salary increases, companies are forced to raise the 
prices of their products or services in the market. If there is a problem with inflation, the Central Bank will influence the increase of interest rates to slow down the inflationary pressure. High-interest rates will cause inflation to slow down because companies and consumers will now have a higher cost when borrowing money from banks to finance their investments or consumer appetites. With a more restrictive policy pursued by the Central Bank in the event of inflation, there is a slowdown in market participants' economic activity and thus a slowdown in inflationary pressure (10).

\section{ANALYSIS OF THE FACTORS INFLUENCING THE MOVEMENT OFTHE EXCHANGE RATE ON FOREIGN EXCHANGE MARKET - ECONOMIC FACTORS}

Factors influencing the currency rates can be divided, among other ways, into economic, political, and natural. However, macroeconomic factors play a fundamental role in changing the exchange rate value (11). Economic factors influencing the exchange rate movement are numerous. Still, a macroeconomic analysis could be highlighted as represent a fundamental analysis of changes in the value of the exchange rate in the foreign exchange market (12). In-

The macroeconomic factors play a fundamental role in changing exchange rate value.

flation is the loss of value of money that occurs due to excessive issuance of money to the extent that exceeds the needs of trade in goods and services. The consequences of inflation are: increase in the prices of goods and services, a decrease in the real value of the population's income, an increase in the price of credit funds due to the rise in interest rates, etc. (13). Then, unemployment is a socio-economic phenomenon when part of the population is unable to work. The high level of unemployment primarily affects social tensions and reduced the mass of real incomes of the people. The budget deficit occurs when the state budget expenditures are higher than the budget revenues. It affects the accelerated rise in the inflation rate. The level of the budget deficit is regulated by increasing budget revenues or reducing budget expenditures. Gross domestic product (GDP) is one of the basic indicators that shows the general state of the national economy of a country. GDP growth leads to an increase in the value of the national currency. The consumer price index is a general indicator of inflation. It shows changes in the price level of products that mainly enter the "consumer basket". The growth of prices of industrial products shows changes in the price levels of products intended for further production. The unemployment rate is the percentage of unemployed in relation to the total working-age population. The rise in unemployment is usually ac- 
companied by a fall in the value of the national currency. The trade balance is the size of the difference between a country's exports and imports (10). If exports are higher than imports, the trade balance is positive, and if imports are higher than exports - the trade balance is negative. Increasing the positive difference or decreasing the negative difference increases the value of the national currency. Then, the movement of oil and energy prices as the price of oil rises, the US dollar rises, while the value of the currency of countries that depend on oil imports - falls.

\section{ANALYSIS OF POLITICAL FACTORS INFLUENCING CHANGES IN THE VALUES EXCHANGE RATE ON THE FOREIGN EXCHANGE MARKET}

Among the political factors influencing the movement of the national currency's value are the following: wars, terrorist attacks, elections, military coup, government resignations (14); (15). Wars can greatly affect the change in the value of the national currency. Namely, when the war is ongoing, the economy cannot function in full, and the value of the national currency exchange rate decreases in most cases. Also, the countries that deal with the production and export of weapons are then in a positive balance because their exports increase, and the trade balance gets an even bigger positive difference. One of the compelling examples is undoubtedly the value of the Serbian dinar currency after the First World War, when the dinar was one of the most convertible currencies in the world, thanks to the wise policy of the then Serbian government (16). Terrorist attacks can affect the exchange rate's value by introducing unrest into the consumer population through intimidation of attacks (recurrence of attacks), which can be characterized by a decrease in demand when the exchange rate de facto changes or the value of the national currency decreases. One of the terrorist attacks that affected the change in the exchange rate is the one that took place in New York on September 11, 2001. Figure 1 shows the USD's fall within nine days for a dramatic 800 pips (from 16600 to 1.5800 ).

Elections and other politically important changes/decisions represent an important item in the formation and change of exchange rate values. Namely, if there is a change in government, it should be obvious what kind of monetary and fiscal policy (and exchange rate policy) is represented by the government that comes to power. In accordance with that, the liberal international market reacts knowing the potential consequences (short-term, medium-term, and long-term) to the exchange rate. In that sense, it influences the increase or decrease in the exchange rate value. 


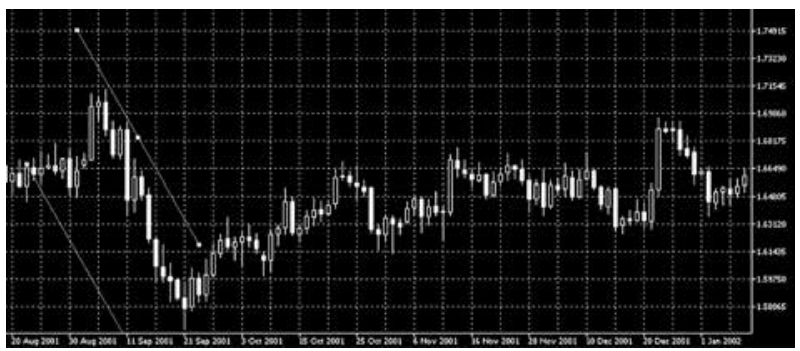

Figure 1. Display of the fall of the USD in relation to $\mathrm{CHF}$ in the period of nine days (September 11, 2001 - September 20, 2001) (17)

\section{ANALYSIS OF NATURAL FACTORS INFLUENCING THE CHANGE IN THEVALUE OF THE EXCHANGE RATE IN THE FOREIGN EXCHANGE MARKET}

Natural disasters also lead to a fall in the value of the currencies of the affected countries. To eliminate the consequences, countries need additional funds that are partially compensated by the primary emissions of central banks, which leads to an increase in the inflation rate. Examples that show how weather disasters affect the change in the value of the exchange rate are presented within the next example. Namely, Japan was hit by an earthquake of magnitude 8.9 , followed by a powerful tsunami. The value of the Japanese yen fell immediately after the disaster, to $0.4 \%$ against the US dollar (18). However, the circumstances were in a sense good for Japan because when the "overseas" capital was transferred to the yen, the currency strengthened during the period of uncertainty after the natural disaster. Another potential reason for the strengthening of the yen is that in the period after the crisis, Japan influenced the liquidation of its non-yen-related portfolio investments and thus managed to channel problems with the exchange rate due to natural disasters (18). The result of Japan's efforts to maintain exchange rate value resulted in a remarkable appreciation of the JPY that threatened to lead to a sharp decline. Then, thanks to good monetary policy measures, the Central Bank of Japan intervened in the international foreign exchange market, and one trillion JPY was sold. Based on this activity, the JPY returned close to the initial ratio from USD to 80.20 (from the previous value of 77.10) (19) (20).

Another example is the situation in New Zealand. Namely, In February 2011, a magnitude 6.3 earthquake killed at least 75 people and significantly damaged the New Zealand economy. After the disaster, the New Zealand dollar (NZD, colloquially 


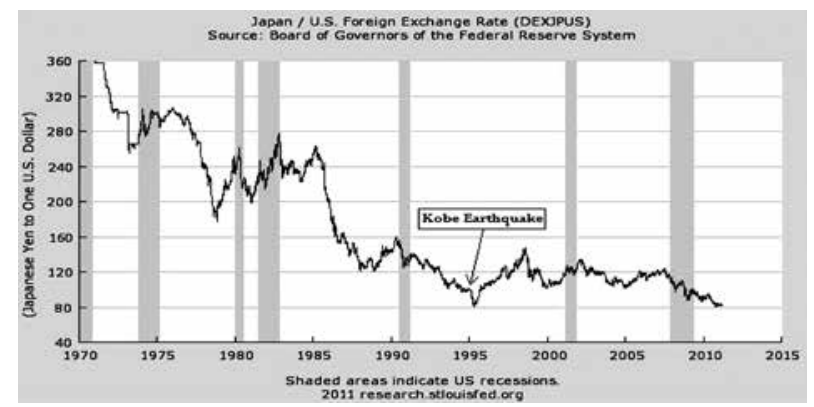

Figure 2. JPY depreciation against the USD during the Kobe earthquake in 1995 (19)

called kiwi) fell by $2 \%$ against the USD. Bloomberg reported that at one point, the NZD fell to $\$ 74.55$. What was characteristic of this catastrophe was that the depreciation lasted significantly longer than was the case with Japan (19) (21). The Haitian gourde (fr. gourde, the national currency of Haiti) experienced serious growth after a magnitude 7.0 earthquake in January 2010. According to the New York Times, the national currency of Haiti strengthened by $25 \%$ and the exchange rate reached the level of 30 gourdes for one USD (21). There are several explanations for this situation. Namely, the decline in the price of imported oil kept more money in Haiti, affecting prevention from a drastic appreciation. Another factor that is stated is that a few months after the natural disaster, there was an influx of a large amount of foreign donations, which again influenced the depreciation of the gourd (21); (22).

\section{RISKS}

This paper confirms that macroeconomic factors have a fundamental influence on the change in the value of the exchange rate (23). In addition to the mentioned influence factors, it is important to mention those such as mass consumer psychology as well as the role of speculators in the money market. As Keynes stated, in addition to the energy and ability of a professional investor and speculator to assess how much the market will be worth, there is also the importance of analyzing the impression of mass psychology, which should be made periodically (25). Also, monetary and fiscal policy plays a significant role in the implementation of government policy towards developments in the international foreign exchange market. In international circles dealing with discussions on the existence and management of risks related to exchange rate fluctuations, we can notice there are still those who argue that it is impossible to do risk management. At the same time, there are counter-argu- 
ments for such claims (25). Risk management is a process that involves the creation of the right environment, the formation of a proper structure for risk management, analysis of risk factors and activities as well as the formation of adequate internal control (26). There are the following types of risk exposure and aspects of depreciation: transaction exposure, economic exposure, translation exposure (25). One of the potential options for risk management in the expected factors influencing the change in the exchange rate is the concept of hedging, which is based on the assumption that the change in the current price in the future will follow the same development path the same dynamics. In essence, the goal of hedge management is to close a transaction at a median price in the future in the country, to eliminate its risk, or to expose itself to sudden price fluctuations.

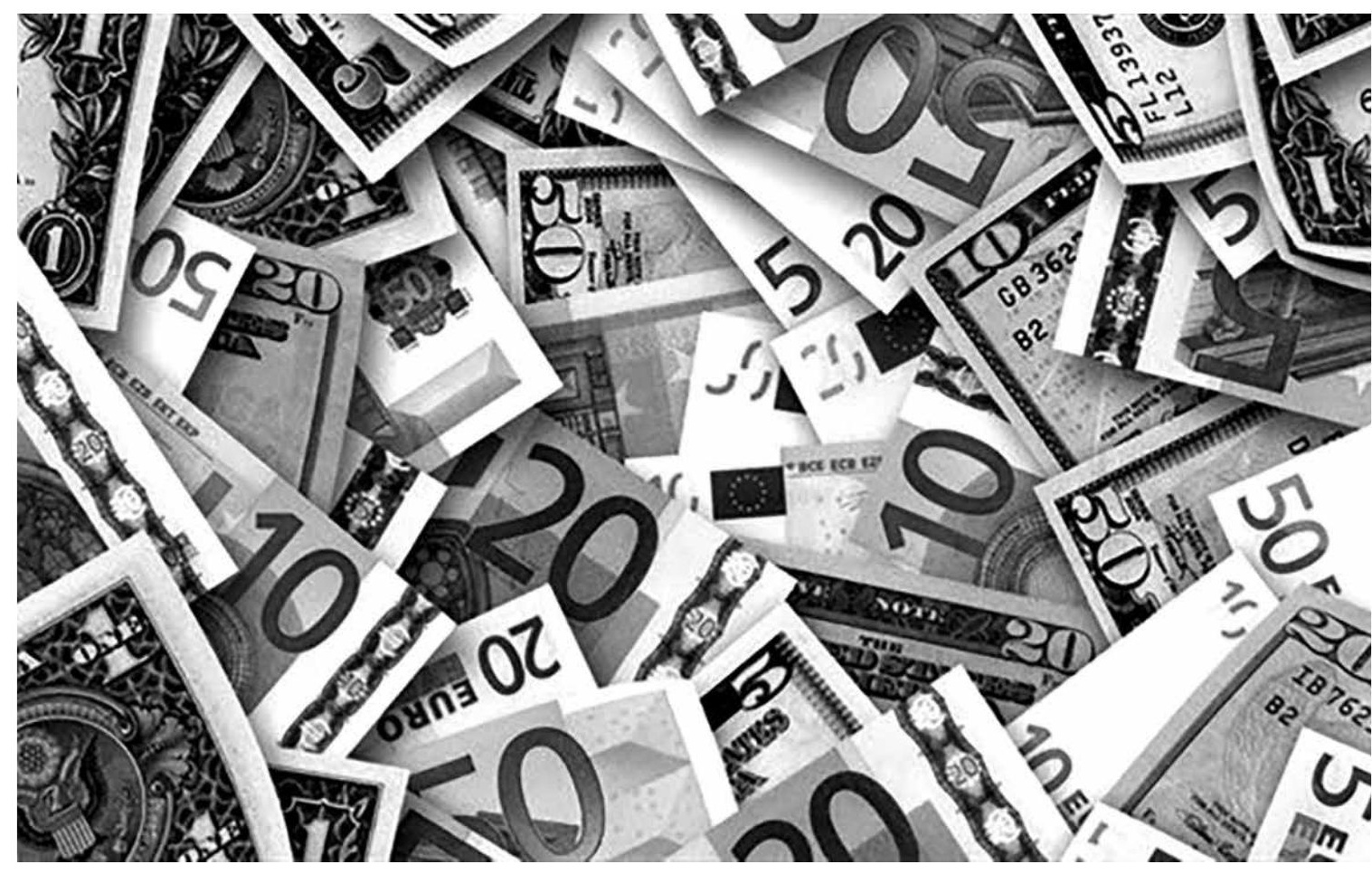

\section{CONCLUSION}

The paper presents a brief genesis of the development of the foreign exchange market and its participants. Also, the factors influencing the change in the movement of the exchange rate are presented. It is defined in which way the course changes and 
the role of the participants in that process. As mentioned earlier, the development of the foreign exchange market is directly proportional to the business's success, and thus (indirectly) to the factors that affect the price of currencies. The paper analytically presents the factors influencing the Forex market, and it can be concluded that any significant impact has effects not only on the national currency but also on the national economy. This influence does not have to affect only a specific currency but can have an extended/secondary influence on a number of interdependent currencies (because the value of one currency is measured in relation to the value of another). Purchasing power parity sometimes cannot be confirmed in reality, and it happens that, although the magnitude of changes in inflation in the observed countries is known, the expected effect of the percentage change in the exchange rate in accordance with purchasing power parity does not occur. The main argument is that the price change drives quotas in the foreign exchange market, while everything else is of a second type. Also, multinational corporations can always hedge over risks and, thanks to their knowledge, actually prevent the risk of "dangerous" quotas and discrepancies in the differences between national currencies. The process of forecasting the factors influencing the international exchange rate is an essential aspect of eliminating the expected effects and understanding the exchange rate's further movement. All these measures can significantly contribute to the fight against uncertainty in the foreign exchange market, leading to safer and more certain operations.

\section{LITERATURE}

1. Kapor, P. (2009). Međunarodne finansije i bankarstvo, Univerzitet Megatrend, Beograd

2. Stojanović, I. (2001). Ekonomija, Univerzitet Megatrend, Beograd

3. Gulan, B. Stamenović, M (2016). Obećanja i očekivanja i trgovanje na međunarodnom deviznom tržištu - Forex, BKC

4. Graucan V., Mairoescu T. (2017): "Introduction to the foreign exchange market", Journal of knowledge Management, Economics and Information Technology. ISSN 2069-5934

5. McLeod, G.(2017). "Forex Market Size: A Traders Advantage", Daily FX. Available at: https://www.dailyfx.com/forex/education/trading_tips/ daily_trading_lesson/2014/01/24/FX_Market_Size.html, Accessed on: (10. 02. 2017

6. Jelisavac Trošić, S. (2020). "Multinacionalne kompanije u međunarodnom pravu", Nedržavni akteri u međunarodnom pravu, (ur) Mihajlo Vučić, str 153-173, Institut za međunarodnu politiku i privredu, Beograd,

7. Jovanović Gavrilović, P. (2004): Međunarodno poslovno finansiranje, Ekonomski fakultet, Beograd

8. OANDA. "Understanding Leverage - What You Don't Know Can Hurt You", Avaiable at: https://www.oanda.com/forex-trading/learn/intro-tocurrency-trading/benefits/leverage, Accessed on: 12. 02. 2017 
9. Dominguez K. (1998). “Central Bank intervention and exchange rate volatility", Journal of International Money and finance, 17.

10. Ramasamy R, Karimi Abar S. (2017): "Influence of macroeconomic Variables on Exchange Rates", Journal of Economics, business and management, Vol. 3, No. 2, February 2015.

11. Canales Kriljenko J., Habermeier K. (2017). Structural Factors Affecting Exchange Rate Volatility: A Cross-section study, Available at: http://www.imf.org/external/pubs/ft/wp/2004/wp04147.pdf , Accessed on 14.10.2019

12. Patel, P. et al. (2016). Factors affecting currency exchange rate, economical formulas and prediction models, Vol. 3, Issue 3, March 2014, ISSN 2319-4847

13. Stamenovic M., Stamenovic K. (2014). Forecasting new technology in case of forex and equity markets, Eurobrand conference, Zrenjanin 2014.

14. Johnston R., Yan Sun (2017). IMF working paper. Some evidence on Exchange rate determination Industrial countries. Available at: https://www.imf.org/external/pubs/ft/wp/wp9798.pdf, Accessed on 15.01.2020

15. Lawrence Broz J., Frieden J. A. (2017): The political economy of exchange rates. Available at: https://scholar.harvard.edu/files/jfrieden/files/PEofERHandbook.pdf, Accessed on: 10.01.2020

16. Monetarna politika 1918-1938 (1938), Ministarstvo finansija, Beograd.

17. Metaquotes software (2017), preuzeto januara 2017.

18. Nanto D. et all. (2011). Japans 2011 Earthquake and Tsunami: Economic effects and ations for the US. Congresional research service, Available at: https://fas.org/sgp/crs/row/R41702.pdf, Accessed on 10.01.2020

19. Reuters. (2017). Available at: http://www.reuters.com/article/ us-japan-quake-kobe-idUSTRE72C2BW20110313, Accessed on 14.01.2019

20. forexblog. (2017) Available at: http://www.forexblog.org/2011/03/ wild-ride-for-the-yen.html, Accessed on: 01.10.2019

21. Inter American Development Bank research Department. (2010). The economics of natural disasters. USA

22. Des Roches R. et all. (2010): Overview of the 2010 Haiti Earthquaqe. Available at:https://escweb.wr.usgs.gov/share/mooney/142.pdf, Accessed on 12.02.2020

23. Canales Kriljenko J., Habermeier K. (2017): Structural Factors Affecting Exchange Rate Volatility: A Cross-section study, Available at: http://www.imf.org/external/pubs/ft/wp/2004/wp04147.pdf, Accessed on 14.05.2020

24. Isard P. (1980): International Finance discussion papers, Available at: https://www.federalreserve.gov/pubs/ifdp/1980/171/ifdp171.pdf. Accessed on 14.05.2020

25. Madura J., Fox R. (2011): International financial Management, South Western Cengage Learning, US

26. Casu Barbara, Giardone Claudia, Moluneyx Philip. (2006): Introduction to banking. Pearson Education, Harlow, England
KAKO MOŽEMO POSMATRATI PROMENE DEVIZNOG KURSA? PREGLED ODABRANIH FAKTORA UTICAJA NA MEĐUNARODNO DEVIZNOTRŽIŠTE REZIME

Ključne reči: međunarodno devizno tržište, devizni kurs, faktori uticaja na tržište valuta

U okviru rada definisani su učesnici na međunarodnom deviznom tržištu kao i uticaj prirodnih, političkih i ekonomskih faktora na kretanje deviznog kursa, i analiza okolnosti koje mogu doprineti promeni kursa. Opšti cilj rada jeste da prezentuje analizu deviznog kursa kroz makroekonomske pojave, kao i da definiše faktore uticaja na promenu deviznog kursa, i uticaj na rad učesnika u tom procesu. Kao mere menadžmenta rizika kojima se može prevenirati uticaj značajnih faktora definisanih u radu, određene su i mere i tipovi izlaganja rizicima. 